\title{
KEPALA SEKOLAH DAN KINERJA PEGAWAI TATA USAHA
}

\author{
Najewan $^{\varpi 1}$, Asrul ${ }^{2}$, Apriani Safitri $^{3}$ \\ Program Studi Administrasi Pendidikan, Universitas Muhammadiyah \\ Kendari123 \\ Email: najewan15@gmail.com
}

\begin{abstract}
ABSTRAK
Tujuan dalam penelitian ini adalah untuk mengetahui peran kepala sekolah dalam meningkatkan kinerja pegawai tata usaha pada Madrasah Tsanawiyah Negeri 3 Konawe Kabupaten Konawe. Jenis penelitian ini adalah kualitatif-deskriptif. Teknik pengumpulan data yang digunakan dalam penelitian ini berupa observasi, wawancara, dan dokumentasi. Teknik analisis data yang digunakan dalam penelitian ini adalah seleksi data, klasifikasi data dan menarik kesimpulan. Berdasarkan hasil penelitian dan pembahasan, menunjukan bahwa peran kepala sekolah dalam meningkatkan kinerja pegawai tata usah pada Madrasah Tsanawiah Negeri 3 Konawe Kabupaten Konawe yakni: kepala sekolah senantiasa melakukan kegiatan bimbingan dan memberiakan bantuan terhadap pembaruan pengelolaan administrasi sekolah dengan menggunakan teknologi yang lebih memadai dalam kinerja tata usaha, memberikan upah tambahan sebagai bentuk apresiasi terhadap pegawai yang menunjukan kinerjanya dan sebaliknya memberikan punishment dengan teguran terhadap pegawai yang malas dan memiliki kinerja rendah, melakukan komunikasi dan koordinasi dalam menyelasaikan masalah dalam pencatatan administrasi, pengelompokan, pengarsipan maupun dalam pelaporan administrasi sekolah. Dengan demikian seluruh kinerja pegawai tata usaha yang meliputi: mempersiapkan, melaksanakan, mengarsipkan, mengelompokkan, memelihara dan melaporkan seluruh administrasi sekolah dapat dilaksanakan secara efektif dan efisien.
\end{abstract}

Kata Kunci: Peran Kepala Sekolah; Kinerja Pegawai Tata Usaha

\section{ABSTRACT}

The purpose of this study was to determine the role of the principal in improving the performance of administrative staff at Madrasah Tsanawiyah Negeri 3 Konawe, Konawe Regency. This type of research is qualitative-descriptive. Data collection techniques used in this study were observation, interviews, and documentation. Data analysis techniques used in this study were data selection, data classification and drawing conclusions. Based on the results of research and discussion, it shows that the role of the principal in improving the performance of administrative staff at Madrasah Tsanawiah Negeri 3 Konawe, Konawe Regency, namely: the principal always carries out guidance activities and provides assistance towards reforming school administration management by using technology that is more adequate in administrative performance, providing additional wages as a form of appreciation for employees who show their performance and conversely giving punishment with a warning to employees who are lazy and have low performance, perform communication and coordination in solving problems in administrative records, grouping, filing and reporting in school administration. Thus all administrative staff performance 
which includes: preparing, implementing, filing, classifying, maintaining and reporting all school administration can be carried out effectively and efficiently.

Keywords: Role of the Principal; Administrative Staff Performance

\section{PENDAHULUAN}

Keberhasilan sekolah dalam proses pendidikan didukung dengan adanya tenaga kependidikan yang profesional dalam kinerjanya. Sebagaimana dalam Undang-Undang Republik Indonesia No 20 Tahun 2003 tentang Sistem pendidikan Nasional pasal 1 ayat 5 dan 6 menjelaskan bahwa "tenaga kependidikan adalah anggota masyarakat yang mengabdikan diri dan diangkat untuk menunjang penyelenggaraan pendidikan. Sedangkan pendidik adalah tenaga pendidikan yang berkualifikasi sebagai guru, dosen, konselor, pamong belajar, tutor, instuktur, fasilitator, dan sebutan lain yang sesuai dengan kekhususannya, serta berpartisipasi dalam menyelenggarakan pendidikan".

Dalam menjalankan organisasi sekolah, seorang kepala sekolah harus mampu mengemudikan dan menjalankan organisasinya, dalam artian kepala sekolah harus mampu membawa perubahan karena perubahan adalah tujuan pokok dari kepemimpinan. Sebuah langkah yang penting untuk melaksanakan perubahan ialah dengan memperkuat perilaku inovatif kepada anggota, kelompok dan organisasi itu sendiri, (Anjar et al., 2020). Kepala sekolah sebagai penentu kebijakan di sekolah juga harus memfungsikan perannya secara maksimal dan mampu memimpin sekolah dengan bijak dan terarah serta mengarah kepada pencapaian tujuan yang maksimal demi meningkatkan kualitas dan mutu pendidikan di sekolahnya yang tentu saja akan berimbas pada kualitas lulusan anak didik sehingga membanggakan dan menyiapkan masa depan yang cerah. Kepala sekolah sebagai administrator dan manajer pendidikan memegang kedudukan yang sangat penting, karena merupakan faktor penentu keberhasilan sekolah dalam menjalankan peran dan fungsinya di masyarakat, ia juga turut menetukan keberadaan sekolah tersebut di tengah-tengah masyarakat dan kemampuan dalam merespon kebutuhan-kebutuhan dan harapan masayarakat Mengingat kedudukan kepala sekolah begitu penting maka dalam penilaian kinerja sekolah, kinerja kepala sekolah menjadi salah satu aspek dalam penilaian kinerja sekolah, karena berkat kepemimpinannya inilah akan menentukan baik-tidaknya kinerja sekolah yang dipimpinnya, (Herawan, 2008).

Oleh karena itu, kepala sekolah harus mempunyai wawasan, keahlian manajerial, mempunyai karisma kepemimpinan dan juga pengetahuan yang luas tentang tugas dan peran sebagai Kepala Sekolah. Dengan kemampuan yang dimiliki seperti itu, Kepala Sekolah tentu saja akan mampu mengantarkan dan membimbing segala komponen yang ada di sekolahnya dengan baik dan efektif menuju ke arah cita-cita sekolah. kepala sekolah harus mempunyai kemampuan dan keterampilan dalam mendukung ketercapaian kinerja dirinya sebagai seorang kepala sekolah. Banyaknya beban kerja dapat diselesaikan kepala sekolah dan bahkan bisa jadi menghasilkan prestasi kerja yang baik jika kepala sekolah memiliki kemampuan maupun keterampilan yang dapat mendukung kesuksesan kepala sekolah dalam menjalankan tugas. Kemampuan maupun keterampilan yang dimaksud adalah kemampuan kepala sekolah melakukan perilaku inovatif, kemampuan dan keterampilan ini akan mendukung seorang kepala sekolah untuk dapat menampilkan kompetensi manajerial yang maksimal. Kepala sekolah banyak mengeluhkan bahwa mereka kekurangan dana untuk mengadakan kegiatan pelatihan disekolah dan mengikutsertakan guru pada pelatihan-pelatihan. Untuk mengatasi ini diharapkan pimpinan sekolah menerapkan kompetensi wirausaha yaitu memiliki kemampuan berpikir inovatif. Ketika melaksanakan prinsip kewirausahaan yang dikaitkan untuk meningkatkan kompetensi guru, maka 
pimpinan seharusnya menciptakan pembaharuan, keunggulan komparatif, dan menggunakan berbagai peluang, (Situmorang et al., 2020).

Tugas dan tanggung jawab kepala sekolah menurut Permendikbud Nomor 20 Tahun 2018 Pasal 8 dinyatakan bahwa: (a) Kewenangan dan tanggung jawab kepala sekolah dalam penyelenggaraan PPK dilaksanakan dalam rangka pemenuhan beban kerja kepala sekolah sesuai dengan ketentuan peraturan perundang-undangan; (b) Dalam rangka pelaksanaan tugas dan tanggung jawab, kepala sekolah berperan sebagai: a) inovator; b) motivator; dan c) kolaborator; (d) Kewenangan dan tanggung jawab guru dalam penyelenggaraan PPK dilaksanakan untuk pemenuhan kebutuhan siswa sesuai dengan ketentuan peraturan perundang-undangan; (e) Dalam rangka pelaksanaan tugas dan tanggung jawab, guru berperan antara lain sebagai penghubung sumber belajar, pelindung, fasilitator; dan katalisator; (f) Kewenangan dan tanggung jawab guru, pengawas sekolah dan tenaga kependidikan lainnya dalam penyelenggaraan PPK dilaksanakan dalam rangka pemenuhan beban kerja sesuai ketentuan peraturan perundang-undangan, (Permendikbud, 2018).

Peran kepala sekolah dalam membantu meningkatkan kualitas satuan pendidikan khususnya kinerja tata usaha dalam melaksanakan tugas dan tanggung jawab dalam meningkatkan mutu layanan pendidikan yang sesuai dengan ketentuan peraturan perundang-undangan. Dalam menjalankan perannya, kepala sekolah harus mengikutsertakan dengan kemampuan kinerja tata usaha yang baik, dalam membantu mengelola administrasi sekolah. Pekerjaan tata usaha bukanlah pekerjaan yang mudah, karena peranan pegawai tata usaha adalah melayani, menyediakan, dan membantu. Tata usaha di sekolah menjalankan tugas dalam berbagai bidang, baik bekerja sama dengan kepala sekolah dan guru, atau bekerja sendiri. Apabila seseorang tidak memiliki standar dan kompetensi di bidang ini, maka pekerjaan yang dikerjakan akan sulit mendapatkan hasil yang maksimal.

Tenaga administrasi sekolah merupakan orang yang memberikan dukungan terhadap program-program kegiatan belajar mengajar. Jadi Tenaga administrasi sekolah adalah kelompok sumber daya manusia di sekolah yang tidak terlibat secara langsung dalam kegiatan pembelajaran siswa dalam memberikan dukungan untuk kelancaran proses pembelajaran dan kegiatan administrasi sekolah. Tenaga administrasi sekolah sering diistilahkan pula sebagai school supporting staff atau school administrative staff, (Suryana et al., 2018). Ketatausahaan adalah kegiatan merangkai aktivitas, menghimpun, mencatat, mengelola, mengadakan, mengirim, dan menyimpan keterangan-keterangan yang diperlukan dalam setiap kerja sama, (Muhlis et al., 2013).

Tata Usaha mempunyai tugas melakukan urusan tata usaha, keuangan, kepegawaian dan penyusunan rencana kerja dan laporan serta akuntabilitas kinerja. Selanjutnya, dalam artikel ini tata usaha diberi pengertian sebagai aktivitas administrasi dalam arti sempit yaitu, kegiatan untuk mengadakan pencatatan dan penyusunan keterangan-keterangan sehingga keterangan-keterangan itu dapat digunakan secara langsung sebagai bahan informasi bagi pimpinan organisasi yang bersangkutan atau dapat dipergunakan oleh siapa saja yang membutuhkannya, (Afriansyah, 2019).

Kegiatan tata usaha mencakup 6 pola fungsi, yaitu: a. Menghimpun, yaitu kegiatankegiatan mencari data mengusahakan tersedianya segala keterangan yang tadinya belum ada, sehingga siap untuk dipergunakan bilamana diperlukan. Seperti, memeriksa jumlah dan alamat surat masuk, surat keluar dan surat ekspedisi; memberi paraf dan nama keterangan pada lembar pengantar surat; dan meneliti tanda kerahasiaan surat. b. Mencatat, yaitu kegiatan membukukan dengan berbagai peralatan tulis keterangan yang diperlukan sehingga terwujud tulisan yang dapat dibaca, dikirim dan disimpan. Seperti, 
mencatat surat masuk, surat keluar dan surat ekspedisi pada pengantar surat, kartu kendali serta ke dalam buku agenda. c. Mengelolah, yaitu bermacam kegiatan mengerjakan keterangan- keterangan dengan maksud menyajikan dalam bentuk yang lebih berguna. Seperti, mengelolah buku induk kepegawaian dan peserta didik; mengelolah surat masuk dan surat keluar; memberikan disposisi pada lembar disposisi yang tersedia. d. Menggandakan, yaitu kegiatan memperbanyak dengan berbagai cara dan alat. Seperti, menggandakan surat masuk, surat keluar dan surat ekspedisi sebagai arsip salinan. e. Mengirim, yaitu kegiatan menyampaikan dengan berbagai cara dan alat dari satu pihak kepada pihak lain. Seperti, mengirim surat tugas dan surat edaran kepada yang diberi tugas maupun kepada pejabat atau instansi lain. f. Menyimpan, yaitu kegiatan menaruh dengan berbagai cara dan alat di tempat yang tertentu dan aman. Seperti, menyimpan arsip surat masuk, suat keluar dan surat ekspedisi ke dalam almari berkas berdasarkan berdasarkan golongan surat, (Amiruddin, 2017).

Pada Madrasah Tsanawiyah Negeri 3 Konawe Kabupaten Konawe dibutuhkan konsentrasi kepemimpinan dalam arti kesungguhan dalam mencapai tujuan organisasi dengan cara memelihara para anggotanya, berinisiatif dan berkreativitas dalam menjalankan tugas-tugasnya sehingga terjadi hubungan proses administratif dan akan saling mengaitkan proses administrasi yang pada akhirnya akan tercipta keserasian antara tujuan organisasi dan usaha-usaha individu dalam kinerjanya sekaligus meningkatkan kualitas diri.

Oleh karena itu, kepala sekolah memiliki peran penting dalam mengembangkan kinerja pegawai tata usaha yang ada. Norma (2014: 21) menjelaskan bahwa pegawai tata usaha di sekolah harus bisa bekerja disemua bidang yang ditugaskan oleh kepala sekolah dan kepala tata usaha. Tugas pegawai tata usaha meliputi: membantu proses belajar mengajar, urusan kepegawaian, keuangan, sarana dan prasarana, humas, persuratan dan pengarsipan, dan administrasi layanan khusus. Untuk dapat membangun sistem penyelenggaraan pendidikan sekolah sebagaimana yang ditawarkan oleh Madrasah Tsanawiyah Negeri 3 Konawe Kabupaten Konawe, maka kunci utamanya adalah sekolah tersebut harus memiliki Pegawai tata usaha yang handal (berkualitas). Agar bisa memiliki Pegawai tata usaha yang handal, maka sekolah tersebut harus melakukan berbagai upaya dan strategi dalam mengelola dan mengembangkan Kinerja Pegawai tata usaha semaksimal mungkin. Peranan pegawai tata usaha sering luput dari pantauan banyak orang sehingga pegawai tata usaha dianggap masih belum memberikan kontribusi yang optimal terhadap peningkatan mutu pendidikan. Sangat jarang kita temui seorang pegawai tata usaha mendapatkan pendidikan dan pelatihan serta seminar. Fakta tersebut dengan jelas memberikan kita gambaran bahwa tidak dapat dinaifkan pegawai tata usaha sebagai tenaga kependidikan di tingkat sekolah belum optimal atau belum sesuai dengan harapan. Hal ini tentu harus mendapat perhatian serius dari segenap pihak mengingat peran dan fungsi pegawai tata usaha sebagai salah satu penyelenggara pendidikan diperlukan kinerja yang optimal guna menunjang penyelenggaraan pendidikan yang berkualitas. Salah satu yang bisa dilakukan untuk meningkatkan kinerja pegawai TU sekolah salah satunya adalah dengan membangun kepercayaan baik antar sesama pegawai maupun dengan pimpinan terutama kepala sekolah, (Syamsuddin, 2015). Namun berdasarkan studi pendahuluan yang penulis lakukan di Madrasah Tsanawiyah Negeri 3 Konawe Kabupaten Konawe, ditemukan gejala-gejala dalam pelaksanan tugas-tugas administrasi sekolah sebagai berikut: (1) ada beberapa pegawai tata usaha belum paham dalam mengoperasikan komputer, sehinga banyak pekerjan-pekerjan yang terkait dengan pengunan komputer tidak bisa diselesaikan secara tepat; (2) ada beberapa pegawai tata usaha belum bisa mempersiapkan dan mengolah proses dalam surat menyurat; (3) ada sebagian pegawai tata usaha belum paham 
dalam mengurus bagaimana penyimpanan, pemeliharan dan pengawetan arsip. Dengan demikian tujuan dalam penelitian ini adalah untuk mengetahui Peran Kepala Sekolah dalam meningkatkan kinerja pegawai tata usaha pada Madrasah Tsanawiyah Negeri 3 Konawe Kabupaten Konawe.

\section{METODE}

Jenis penelitian yang digunakan untuk mengkaji Peran Kepala Sekolah Dalam Meningkatkan Kinerja Pegawai Tata Usaha Pada Madrasah Tsanawiyah Negeri 3 Konawe, Kabupaten Konawe adalah deskriptif-kualitatif. Adapun subjek dalam penelitian ini yaitu kepala sekolah dan pegawai tata usaha Madrasah Tsanawiyah Negeri 3 Konawe Kabupaten Konawe yang berjumlah 6 orang, yang terdiri dari kepala sekolah dan 5 orang pegawai tata usaha Madrasah Tsanawiyah Negeri 3 Konawe. Teknik pengumpulan data yang diperlukan dalam penelitian ini yaitu, (1) observasi langsung yakni observasi digunakan peneliti untuk mengamati secara langsung berbagai peran kepala sekolah dalam meningkatkan kinerja pegawai tata usaha pada Madrasah Tsanawiyah Negeri 3 Konawe, termaksud pula didalamnya, mengamati proses berlangsungnya aktifitas yang dilakukan kepala sekolah dan pegawai tata usaha dalam proses meningkatkan kinerja tata usaha. (2) wawancara mendalam yakni Metode wawancara yang digunakan peneliti dalam penelitian ini adalah wawancara semiterstruktur (semistructure interview), merupakan jenis wawancara dalam kategori in depth interview, dimana dalam pelaksanaan lebih bebas bila di bandingkan dengan wawancara terstruktur. Tujuan dari wawancara jenis ini adalah untuk menemukan permasalahan secara lebih terbuka dimana pihak yang diajak wawancara diminta pendapatnya atau ide-idenya tentang peran kepalah sekolah di Sekolah tersebut. wawancara merupakan alat pengumpul data (informasi) yang langsung tentang beberapa jenis data sosial, dan (3) studi dokumentasi, hasil dokumentasi yang dilakukan itu, selanjutnya dikaitkan atau direlevansikan dengan hasil yang diperoleh pada penelitian ini sebagai bentuk kajian ilmiah pembahasan hasil penelitian ini.

Teknik analisa data yang digunakan pada penelitian ini adalah teknik analisis deskriptif-kualitatif berdasarkan kenyataan yang diperoleh di lapangan.. Sebagaimana yang dikemukakan oleh Miles dan Huberman (Sugiyono, 2018) dimana komponen reduksi data dan sajian data dilakukan bersamaan dengan proses pengumpulan data. Setelah data terkumpul, maka keempat komponen analisis yaitu (pengumpulan data, reduksi data, sajian data dan penarikan kesimpulan) saling berinteraksi.

\section{HASIL DAN PEMBAHASAN \\ Hasil Penelitian}

Berdasarkan hasil penelitian yang dilakukan peneliti di Madrasah Tsanawiah Negeri 3 Konawe guna meningkatkan peran kepala sekolah dalam meningkatkan kinerja pegawai tata usaha, kepala sekolah/madrasah melaksanakan perannya sebagai Inovator, motivator, dan kolaborator.

\section{Peran kepala sekolah sebagai inovator dalam meningkatkan kinerja tata usaha}

Sebagai seorang Inovator di lembaga pendidikan Islam kepala madrasah harus mampu memberikan petunjuk dan pengawasan, meningkatkan kemauan tenaga kependidikan, membuka komunikasi dua arah, dan mendelegasikan tugas. Kemampuan yang harus diwujudkan kepala madrasah sebagai Inovator dapat dianalisis dari kepribadian, pengetahuan terhadap tenaga pendidikan, visi dan misi madrasah, kemampuan mengambil keputusan dan kemampuan berkomunikasi. 
Berdasarkan hasil observasi yang dilakukan di Madrasah Tsanawiah Negeri 3 Konawe ditemukan bahwa kepala sekolah Madrasah Tsanawiah Negeri 3 Konawe Kabupaten Konawe dalam usahanya untuk membentuk sikap disiplin para pegawai tata usaha, beliau terlebih dahulu melaksanakan sikap disiplin tersebut, misalnya dengan datang ke sekolah lebih awal serta memulai dan mengakhiri jam kerja sesuai dengan waktu yang telah ditetapkan. Hal ini sesuai dengan hasil wawancara dengan kepala sekolah Madrasah Tsanawiah Negeri 3 Konawe yang menyatakan bahwa: "Sebagai kepala sekolah tentu harus menjadi teladan bagi semua pegawai terutama guru dan tata usaha terutama dalam hal membentuk kedisiplinan dan bekerja dengan sungguh-sungguh, selalu bersikap terbuka sehingga permasalahan yang terjadi di sekolah lebih mudah dikomunikasikan, selalu mengawasi minimal sebulan sekali secara langsung melihat kinerja tata usaha, menghimbau agar kinerja pegawai tata usaha senantiasa melakukan perubahan dalam hal penataan administrasi sekolah baik itu data guru dan siswa dengan memanfaatkan komputer sekolah sebagai tempat menyimpan file sehingga ketika dibutuhkan data administrasinya selalu tersedia karena semua pekerjaan administrasi sekolah termasuk kearsipan sekolah dikerjakan oleh tata usaha".

Dengan melaksanakan setiap tugasnya secara tepat waktu diharapkan bisa menjadi contoh bagi para pegawai tata usaha serta bisa memberikan dampak positif untuk meningkatkan kualitas pegawai tata usaha yang ada di madrasah tersebut. Selain itu kepala sekolah dalam melaksanakan perannya sebagai Inovator dalam meningkatkan kinerja pegawai tata usaha yakni dengan cara membantu para pegawai tata usaha dalam meningkatkan pertumbuhan pribadi dan jabatannya dan juga para staf madrasah lainnya sehingga proses pengelolaan administrasi sekolah dilaksanakan secara baik, sehingga berdampak pada situasi proses kinerja yang lebih efektif dan efisien. Melakukan supervisi, kegiatan pengawasan dan pengendalian yang dilakukan kepala sekolah merupakan kontrol agar kinerja tata usaha di Madrasah Tsanawiah Negeri 3 Konawe lebih terarah pada tujuan yang telah ditetapkan. Pengawasan dan pengendalian merupakan tindakan preventif untuk mencegah agar kinerja tata usaha tidak melakukan penyimpangan dan lebih berhati-hati dalam melaksanakan pekerjaannya.

Peran kepala sekolah sebagai innovator dalam meningkatkan kinerja pegawai tata usaha pada Madrasah Tsanawiah Negeri 3 Konawe diwujudkan dalam kegiatan pengelolaan administrasi sekolah dengan memanfaatkan komputer atau labtop dalam pengelolaan administrasi sekolah. Selain itu, kepala sekolah juga secara rutin memantau atau mengawasi kinerja pegawai tata usaha dalam melaksanakan tugasnya dalam membantu kepala sekolah dalam menyelesaikan administrasi sekolah dan menyimpannya dalam bentuk arsip. Kegiatan pengawasan terhadap kinerja tata usaha tersebut dilaksanakan setiap bulan dengan tujuan memberi masukan yang bersifat membangun agar profesionalitas kinerja pegawai tata usaha meningkat menjadi lebih baik. Pegawai tata usaha juga ditekankan untuk bekerja dengan menggunakan komputer sehingga semua pengelolaan administrasi sekolah lebih efektif dan efisien.

\section{Peran kepala sekolah sebagai motivator dalam meningkatkan kinerja tata usaha}

Berdasarkan hasil observasi yang dilaksanakan di Madrasah Tsanawiah Negeri 3 Konawe ditemukan bahwa sebagai seorang motivator kepala Kepala Sekolah Madrasah Tsanawiah Negeri 3 Konawe berusaha memberikan dorongan kepada pegawai tata usaha yang ada di sekolah tersebut agar keprofesionalitasnya meningkat. Ada beberapa upaya yang dilakukan kepala sekolah sebagai seorang motivator agar kinerja pegawai tata usaha selalu ditingkatkan dan bersemangat dalam melaksanakan tugasnya, yakni Kepala Sekolah Madrasah Tsanawiah Negeri 3 Konawe senantiasa berusaha memberikan reward kepada 
kepada pegawai tata usaha yang memiliki kreatifitas tinggi. Selain itu dukungan untuk melanjutkan pendidikan ke jenjang yang lebih tinggi juga diberikan oleh kepala sekolah yang ingin menambah wawasannya. Tidak hanya itu, kepala sekolah juga memberikan masukan kepada para pegawai tata usaha yang mengalami kesulitan dalam menjalankan tugasnya. Sebagai motivator, kepala sekolah memiliki strategi yang tepat untuk memberikan motivasi kepada para pegawai tata usaha dalam melakukan berbagai tugas dan fungsinya. Dorongan dan penghargaan merupakan dua sumber motivasi yang efektif diterapkan oleh kepala sekolah.

Sebagaimana hasil wawancara dengan kepala sekolah Madrasah Tsanawiah Negeri 3 Konawe yang mengemukakan bahwa: "Untuk meningkatkan kualitas kinerja pegawai tata usaha, selaku pimpinan saya senantiasa berusaha memberikan penghargaan kepada para pegawai tata usaha yang memiliki kedisiplinan dalam bekerja. Memberikan motivasi dalam bentuk-bentuk kata-kata penyemangat agar pegawai tata usaha semangat dalam menjalankan tugasnya dan jika ada kesalahan saya langsung menegur dengan memanggil yang bersangkutan diruangan, selain itu untuk meningkatkan keahliannya maka pegawai tata usaha diberikan kesempatan mengikuti pelatihan-pelatihan yang diselenggarakan oleh sekolah ataupun pemerintah daerah terutama dalam pengelolaan administrasi sekolah".

Hal senada diungkapkan pula oleh salah satu informan yang juga kepala tata usaha Madrasah Tsanawiah Negeri 3 Konawe yang mengungkapkan bahwa : "Kepala sekolah biasa memberikan hadiah bagi para pegawai tata usaha yang berkerja sesuai dengan kriteria khususnya mengenai kedisiplinan dalam menjalankan tugas, saya pun pernah dapat hadiah berupa uang tambahan katanya sih saya rajin dan tepat waktu datang dan pulang tetapi kepala sekolah juga tidak sungkan untuk menegur jika kami melakukakn kesalahan. Selain itu, kepala sekolah juga memberikan keleluasaan siapa saja boleh mengikuti pelatihan atau penataran yang diselenggaran oleh lembaga atau yayasan asalkan tidak mengganggu pekerjaan atau rutinitas kegiatan sekolah".

Peran kepala sekolah sebagai motivator dalam meningkatkan kinerja pegawai tata usaha pada Madrasah Tsanawiah Negeri 3 Konawe diwujudkan yakni kepala sekolah memberikan reward kepada pegawai tata usaha yang bekerja dengan giat dan punishment berupa teguran ketika ada kesalahan dalam bekerja, mendorong dan mengapresiasi pegawai tata usaha dalam bentuk kata-kata semangat, membantu para pegawai tata usaha yang memiliki masalah dalam kinerjanya sehingga mereka selalu meningkatkan profesinalitas dalam bekerja. Sebagai seorang pegawai tata usaha diharapkan kinerjanya dapat memberikan dampak positif bagi kemajuan Madrasah Tsanawiah Negeri 3 Konawe Kabupaten Konawe.

\section{Peran kepala madrasah sebagai kalaborator dalam meningkatkan kinerja tata usaha}

Berdasarkan hasil observasi yang dilakukan di Madrasah Tsanawiyah Negeri 3 Konawe ditemukan bahwa sebagai seorang kalaborator upaya yang dapat dilakukan kepala sekolah dalam meningkatkan kinerja pegawai tata usaha yaitu dengan mengikutsertakan pegawai tata usaha dalam penataran-penataran, untuk menambah wawasan para pegawainya, menyelesaikan masalah administrasi sesegera mungkin, karena persoalan administrasi sekolah merupakan hal yang sangat penting bagi Madrasah Tsanawiah Negeri 3 Konawe. Selain itu, kepala sekolah juga membimbing para tenaga tata usaha yang mengalami kesulitan dalam melaksanakan tugasnya contoh, pada saat tata usaha tidak memahami tugas yang akan diberikan dengan antusias kepala sekolah memberikan pemahaman kepada tenaga pegawai tata usaha yang mengalami kesulitan tersebut.

Berdasarkan hasil wawancara peneliti dengan kepala sekolah Madrasah Tsanawiah Negeri 3 Konawe yang mengemukakan bahwa: "Selaku kepala sekolah tentu setiap 
pekerjaan yang dilakukan selalu bekerja sama dengan pegawai lainnya. Dalam hal pengelolaan administrasi sekolah maka selalu bekerja sama dengan pegawai tata usaha. Ketika ada masalah maka wajib untuk sesegera mungkin diselesaikan biasanya melalui rapat atau pegawai tata usaha yang secara langsung berkonsultasi baik itu masalah pembuatan administrasi, pengelompokan administrasi dalam pengarsipan maupun dalam pelaporan, semua itu harus berdasarkan arahan dan instruksi dari saya. Intinya komunikasi dan koordinasi harus senantiasa terjaga".

Sejalan dengan hasil wawancara peneliti dengan Kepala Tata Usaha Madrasah Tsanawiah Negeri 3 yang menyatakan bahwa: "Sebagai pimpinan kepala sekolah selalu memberikan kami arahan dalam melakukan tugas kami sebab kepala sekolah itu sangat disiplin dan teliti sehingga semua pekerjaan biasanya secara langsung dipantau atau kami yang keruangannya berkonsultasi".

Peran kepala sekolah sebagai kolaborator dalam meningkatkan kinerja pegawai tata usaha pada Madrasah Tsanawiah Negeri 3 Konawe yakni kepala sekolah membimbing para pegawai tata usaha yang mengalami kesulitan dalam melaksanakan tugasnya, memberdayakan pegawai tata usaha melalui kerja sama atau kooperatif, dan melakukan kominakasi dan koordinasi dalam menyelasaikan masalah dalam pencatatan administrasi, pengelompokan, pengarsipan maupun dalam pelaporan administrasi sekolah. Hal tersebut dilakukan untuk memberikan yang terbaik untuk Madrasah Tsanawiah Negeri 3 Konawe dengan pengelolaan administrasi yang terkontrol, tersusun dan dilaporkan secara akurat dan tepat waktu

\section{Pembahasan}

\section{Peran kepala sekolah sebagai inovator dalam meningkatkan kinerja tata usaha}

Berdasarkan hasil penelitian yang dilaksanakan di Madrasah Tsanawiah Negeri 3 Konawe Kabupaten Konawe ditemukan bahwa peran kepala sekolah sebagai innovator dalam meningkatkan kinerja pegawai tata usaha pada Madrasah Tsanawiah Negeri 3 Konawe Kabupaten Konawe diwujudkan dalam kegiatan pengelolaan administrasi sekolah dengan memanfaatkan komputer atau labtop dalam pengelolaan administrasi sekolah. Kepala sekolah sebagai seorang inovator harus memiliki strategi yang tepat untuk menjalin hubungan yang harmonis dengan lingkungan, mencari gagasan baru, mengimplementasikan ide-ide baru, mengintegrasikan setiap kegiatan, memberikan teladan kepada seluruh tenaga kependidikan di sekolah, dan mengembangkan model-model pembelajaran yang inovatif. Mulyasa (Putra, 2014).

Kepala sekolah dalam menjalankan perannya sebagai inovator dalam meningkatkan kinerja pegawai tata usaha pada Madrasah Tsanawiah Negeri 3 Konawe Kabupaten Konawe telah terlaksana dengan baik. Hal ini dapat ditunjukan melalui: 1) pengawasan terhadap seluruh kegiatan pegawai tata usaha dalam mengelola administrasi sekolah secara periodik, hasil pengawasan tersebut, dapat dijadikan sebagai bahan evaluasi untuk dijadikan sebagai bahan masukan atau informasi perbaikan selanjutnya, 2) membimbing pegawai tata usaha dalam menata, mengelompokkan dan menyimpan seluruh data administrasi sekolah sebagai arsip sekolah, 3) memberikan dukungan terhadap pembaruan pengelolaan administrasi sekolah dengan menggunakan komputer, sehingga semua pegawai tata usaha dapat mengoperasikan secara mandiri.

\section{Peran kepala sekolah sebagai motivator dalam meningkatkan kinerja tata usaha}

Kepala sekolah memberikan reward kepada pegawai tata usaha yang bekerja dengan giat dalam bentuk upah tambahan dan punishment berupa teguran ketika ada kesalahan dalam bekerja, mendorong dan mengapresiasi pegawai tata usaha dalam bentuk 
kata-kata semangat, membantu para pegawai tata usaha yang memiliki masalah dalam kinerjanya sehingga mereka selalu meningkatkan profesinalitas dalam bekerja. Sebagai seorang pegawai tata usaha diharapkan kinerjanya dapat memberikan dampak positif bagi kemajuan Madrasah Tsanawiah Negeri 3 Konawe Kabupaten Konawe.

Peran kepala sekolah sebagai motivator dalam meningkatkan kinerja pegawai tata usaha yakni: a. peningkatan, usaha untuk meningkatkan pengalaman maupun pendidikan bagi para wakasek, guru maupun staf tata usaha baik melalui pendidikan serta pelatihan, Kebijakan, usaha untuk memberikan rasa nyaman dalam pengaturan jadwal mengajar, b. gaji, usaha pemberian insentif yang memadai untuk guru (khususnya honorer) atau staf tata usaha melalui tunjangan daerah maupun sertifikasi, c. fasilitas, perbaikan fasilitas berupa ruang kerja yang jauh lebih nyaman (khususnya ruang tata usaha) dan ruang kegiatan serta ruang kelas bagi siswa yang juga semakin bagus juga ditunjang dengan kelengkapan untuk ekstrakurikuler, d. angka, berupa poin yang diberikan kepada siswa dalam jumlah yang sama dan bisa bertmbah atau berkurang sesuai dengan prestasi atau pelanggaran yang dilakukan kemudian dilanjutkan adanya reward atau punishment, (Dzaky, 2016). Kepala sekolah bertugas memelihara lingkungan kerja, suasana kerja, membangun prinsip penghargaan dan hukuman (reward dan punishment) yang sistematik.

\section{Peran kepala sebagai kolaborator dalam meningkatkan kinerja tata usaha}

Berdasarkan hasil penelitian yang dilakukan di Madrasah Tsanawiah Negeri 3 Konawe Kabupaten Konawe bahwa peran kepala sekolah sebagai motivator dalam meningkatkan kinerja pegawai tata usaha pada Madrasah Tsanawiah Negeri 3 Konawe Kabupaten Konawe yakni kepala sekolah sebagai kolaborator yakni memberdayakan pegawai tata usaha melalui kerja sama atau kooperatif, dan melakukan komunikasi dan koordinasi dalam menyelasaikan masalah dalam pencatatan administrasi, pengelompokan, pengarsipan maupun dalam pelaporan administrasi sekolah. Hal tersebut dilakukan untuk memberikan yang terbaik untuk Madrasah Tsanawiah Negeri 3 Konawe dengan pengelolaan administrasi yang terkontrol, tersusun dan dilaporkan secara akurat dan tepat waktu. Kepala sekolah yang baik bersikap konstruktif terhadap situasi yang sedang berjalan. Kemampuan untuk mendengar orang lain dan menghargai pendapat orang lain serta memberikan kepercayaan kepada semua warga sekolah akan memberikan dampak yang positif terhadap perkembangan lembaga sekolah yang ia pimpin sekaligus memberikan kesempatan kepada semua pihak untuk menyelesaikan permasalahan yang di hadapi, (Mukhtar, 2015). Tugas kepala sekolah sebagai kolaborator yakni membimbing pegawai tata usaha meliputi penyususnan program kerja dan pembagian tugas ketatausahaan dan selalu dipantau dalam menjalankan tugasnya sehari-hari. Melalui pemantauan tersebut mereka dievaluasi dan dikendalikan kinerjanya secara periodik.

Peran kepala sekolah dalam meningkatkan kinerja pegawai tata usah pada Madrasah Tsanawiah Negeri 3 Konawe Kabupaten Konawe telah terlaksana dengan baik yakni: 1) peran kepala sekolah sebagai inovator meliputi: kegiatan pengawasan, membimbing, dan memberikan dukungan terhadap pembaruan pengelolaan administrasi sekolah dengan menggunakan komputer, sehingga semua pegawai tata usaha dapat menyelesaikan pengelolaan administrasi sekolah dengan baik. 2) peran kepala sekolah sebagai motivator meliputi: memberikan reward dalam bentuk upah tambahan kepada pegawai tata usaha yang bekerja dengan giat, memberikan punishment terhadap kesalahan yang dilakukan oleh pegawai tata usaha berupa teguran secara langsung, memberikan semangat dalam bentuk kata-kata, membantu para pegawai tata usaha yang memiliki masalah dalam kinerjanya sehingga mereka dapat menyelasaikan pekerjaan secara efektif dan efisien. 3) peran kepala sekolah sebagai kolaborator meliputi: memberdayakan pegawai 
tata usaha melalui kerja sama atau kooperatif, melakukan komunikasi dan koordinasi dalam menyelasaikan masalah dalam pencatatan administrasi, pengelompokan, pengarsipan maupun dalam pelaporan administrasi sekolah. Dengan demikian seluruh kinerja pegawai tata usaha yang meliputi: mempersiapkan, melaksanakan, mengarsipkan, mengelompokkan, memelihara dan melaporkan seluruh administrasi sekolah dapat dilaksanakan secara efektif dan efisien.

\section{SIMPULAN}

Berdasarkan hasil penelitian dan pembahasan dapat ditarik kesimpulan tentang peran kepala sekolah dalam meningkatkan kinerja pegawai tata usaha pada Madrasah Tsanawiah Negeri 3 Konawe Kabupaten Konawe telah terlaksana dengan baik yakni: 1) peran kepala sekolah sebagai inovator meliputi: kegiatan membimbing, dan memberikan dukungan terhadap pembaruan pengelolaan administrasi sekolah dengan menggunakan komputer, sehingga semua pegawai tata usaha dapat menyelesaikan pengelolaan administrasi sekolah dengan baik serta melakukan pengawasan setiap kinerja pegawai tata usaha. 2) peran kepala sekolah sebagai motivator meliputi: memberikan reward dalam bentuk upah tambahan kepada pegawai tata usaha yang bekerja dengan giat, memberikan punishment terhadap kesalahan yang dilakukan oleh pegawai tata usaha berupa teguran secara langsung, memberikan semangat dalam bentuk kata-kata, membantu para pegawai tata usaha yang memiliki masalah dalam kinerjanya sehingga mereka dapat menyelasaikan pekerjaan secara efektif dan efisien. 3) peran kepala sekolah sebagai kolaborator meliputi: memberdayakan pegawai tata usaha melalui kerja sama atau kooperatif, melakukan komunikasi dan koordinasi dalam menyelasaikan masalah dalam pencatatan administrasi, pengelompokan, pengarsipan maupun dalam pelaporan administrasi sekolah. Dengan demikian seluruh kinerja pegawai tata usaha yang meliputi: mempersiapkan, melaksanakan, mengarsipkan, mengelompokkan, memelihara dan melaporkan seluruh administrasi sekolah dapat dilaksanakan secara efektif dan efisien.

\section{UCAPAN TERIMAKASIH}

Penulis menyampaikan ucapan terima kasih dan penghargaan kepada Bapak Asrul, S.Pd., M.Pd. selaku pembimbing I dan Ibu Apriani Safitri, S.Pd., M.Pd selaku pembimbing II yang telah sabar, tekun, tulus dan ikhlas meluangkan waktu, tenaga dan pikiran memberikan bimbingan, motivasi, arahan, dan saran-saran yang sangat berharga kepada penulis selama menyusun hasil ini, dan seluruh civitas akademika Program Studi Administrasi Pendidikan, Fakultas Keguruan dan Ilmu Pendidikan, Universitas Muhammadiyah Kendari.

\section{DAFTAR PUSTAKA}

Afriansyah, H. (2019). 10. Administrasi Ketatausahaan Sekolah. osf.io. https://osf.io/preprints/w25j6/

Amiruddin. (2017). Kinerja Pegawai Tata Usaha dengan Mutu Layanan Administrasi di Madrasah. Al-Idarah: Jurnal Kependidikan Islam, 7(1), 126-145. http://ejournal.radenintan.ac.id/index.php/idaroh/article/download/2254/1685

Anjar, A., Siregar, M., Toni, Gusman, H. E., HTS, D. I. G., Harahap, S. Z., \& Rokhani, C. T. S. (2020). SPK Untuk Pemilihan Kepala Sekolah Menggunakan Metode Saw dan Profile $\begin{array}{llll}\text { Matching. } \quad U-N E T & \text { Jurnal 26, }\end{array}$ https://www.jiemar.org/index.php/jiemar/article/view/35

Dzaky, A. (2016). Peran Kepala Sekolah Sebagai Motivator Pada Ma Muhammadiyah 1 Banjarmasin. Ittihad, 14(26), 11-18. https://doi.org/10.18592/ittihad.v14i26.869 
Herawan, E. (2008). Kinerja Kepala Sekolah. Jurnal Administrasi Pendidikan UPI, 7(1).

Muhlis, Aswandi, \& M.Syukri. (2013). Manajemen Kinerja Ketatausahaan. Jurnal Pendidikan Dan Pembelajaran, 2(8), 1-10.

Mukhtar. (2015). Kinerja Guru Pada Smp Negeri Di Kecamatan. Jurnal Magister Administrasi Pendidikan, 3, 103-117.

Permendikbud RI No 20 Tahun 2018. (2018). Permendikbud RI No 20 Tahun 2018. 8-12.

Putra, J. A. (2014). Peran Kepala Sekolah Sebagai Inovator Di Sekolah Menengah Pertama Negeri Kota Pariaman. Jurnal Administrasi Pendidikan, 2, 347-355.

Situmorang, B., Rohana, R., Adi, P. N., Hasibuan, N. S., \& Kartikaningsih, R. (2020). Pengaruh Perilaku Inovatif terhadap Kompetensi Manajerial Kepala Sekolah Dasar di Kabupaten Labuhan Batu The Effect of Innovative Behavior on Managerial Competence of Primary School Principals in Labuhan Batu District. Jurnal Penelitian Dan Pengkajian Ilmu Pendidikan: E-Saintika, 4(2), 119-125. https://doi.org/https://doi.org/10.36312/esaintika.v4i2.190

Sugiyono. (2018). Metode Penelitian Kuantitatif, Kualitatif dan R\&D. In Journal of Chemical Information and Modeling (Vol. 53, Issue 9).

Suryana, A., Karim, A. A., \& Sapriya, S. (2018). Manajemen Capacity Building Tenaga Administrasi Sekolah Di Sekolah Laboratorium Upi. Pedagogia, 15(3), 250265. https://doi.org/10.17509/pdgia.v15i3.11021

Syamsuddin. (2015). Pentingya membangun kepercayaan (. Jurnal Al-Ta;Dib, 8(2), 18-34. 